\title{
FAKTOR-FAKTOR YANG BERPENGARUH TERHADAP CURAHAN WAKTU KERJA PADA USAHA PENGGEMUKAN SAPI POTONG DI KABUPATEN CIAMIS
}

\author{
Oleh \\ AGUS YUNIAWAN ISYANTO \\ Fakultas Pertanian Universitas Galuh Ciamis \\ Email: gus_yun69@yahoo.co.id
}

\begin{abstract}
Abstrak
Peningkatan jumlah penduduk dan adanya perubahan pola konsumsi serta selera masyarakat menyebabkan konsumsi daging sapi secara nasional cenderung meningkat sehingga terjadi peningkatan impor. Sebagian besar usaha peternakan sapi potong merupakan usaha rakyat dengan ciri skala usaha rumah tangga dan kepemilikan ternak sedikit, menggunakan teknologi sederhana, bersifat padat karya, dan berbasis azas organisasi kekeluargaan. Peternakan dengan skala kecil tersebut biasanya menggunakan tenaga kerja dalam keluarga. Dalam analisis ketenagakerjaan di bidang peternakan, penggunaan tenaga kerja dinyatakan oleh besarnya curahan tenaga kerja. Penelitian ini dilaksanakan dengan tujuan untuk mengetahui: (1) Curahan waktu kerja pada usaha penggemukan sapi potong, dan (2) Faktor-faktor yang berpengaruh terhadap curahan waktu kerja pada usaha penggemukan sapi potong di Kabupaten Ciamis. Penelitian dilaksanakan di Kabupaten Ciamis sebagai salah satu sentra produksi sapi potong di Provinsi Jawa Barat. Ukuran sampel penelitian sebanyak 100 peternak sapi potong di Kecamatan Panjalu dan Cihaurbeuti, Kabupaten Ciamis, yang dipilih secara purposif sebagai lokasi penelitian. Data yang digunakan berupa data primer usaha penggemukan sapi potong pada tahun 2012. Analisis faktor-faktor yang berpengaruh terhadap curahan waktu kerja pada usaha penggemukan sapi potong dilakukan dengan menggunakan persamaan regresi linier berganda. Hasil penelitian menunjukkan bahwa: (1) Curahan waktu kerja berkisar antara 2,14-5,10 jam/hari, dengan rata-rata 3,65 jam/hari., dan (2) Jumlah kepemilikan ternak dan pekerjaan utama berpengaruh positif dan signifikan terhadap curahan waktu kerja pada usaha penggemukan sapi potong.
\end{abstract}

Kata kunci: sapi potong, curahan waktu kerja, faktor-faktor

\section{PENDAHULUAN}

Laju peningkatan jumlah penduduk yang diikuti dengan perbaikan taraf hidup dan perubahan selera konsumen telah mengubah pola konsumsi yang mengarah pada protein hewani asal ternak. Kebutuhan daging sapi meningkat dari tahun ke tahun, demikian pula impor terus bertambah dengan laju yang makin tinggi, baik impor daging maupun sapi bakalan (Priyanto, 2011).

Peningkatan pertumbuhan ekonomi akan memacu peningkatan konsumsi yang harus diantisipasi, terutama untuk menghindarkan pengurasan cadangan devisa untuk impor daging dan susu (Yusdja dan Ilham, 2007). Salah satu bentuk antisipasi tersebut adalah adanya berbagai kebijakan dan program yang terkait dengan pengembangan usaha ternak sapi potong (Rahmanto, 2004). Namun, kebijakan tersebut belum mampu memenuhi permintaan daging sapi dalam negeri sehingga terjadi peningkatan impor, baik impor sapi bakalan maupun impor daging sapi; untuk mengatasi senjang antara produksi dan pemintaan daging sapi dalam negeri (Winarso, dkk., 2005).

Sebagian besar usaha peternakan sapi potong merupakan usaha rakyat dengan ciri skala usaha rumah tangga dan kepemilikan ternak sedikit, menggunakan teknologi sederhana, bersifat padat karya, dan berbasis azas organisasi kekeluargaan (Azis dalam Yusdja dan Ilham, 2004). Kecilnya skala usaha pemeliharaan sapi potong tersebut disebabkan karena keterbatasan modal, tenaga kerja dan manajemen (Hadi dan Purwantini, 1991a; 1991b; Hadi, dkk., 2002).

Soetriono (2003) menyatakan bahwa biasanya usaha peternakan dengan skala kecil akan menggunakan tenaga kerja dalam keluarga dan tidak perlu tenaga dari luar, karena dalam kegiatan usahanya dilakukan oleh anggota keluarga itu sendiri

Penelitian ini dilaksanakan dengan tujuan untuk mengetahui: (1) Curahan waktu kerja pada usaha penggemukan sapi potong di Kabupaten Ciamis, dan (2) Faktor-faktor yang berpengaruh terhadap curahan waktu kerja pada 


\section{MIMBAR \\ A GRIBISNIS \\ ISSN 2460-4321}

Volume 1・ Nomor 1・Juli 2015

usaha penggemukan sapi potong di Kabupaten Ciamis.

\section{TINJAUAN PUSTAKA}

Pengembangan usaha dibidang peternakan antara lain bertujuan untuk menciptakan lapangan kerja dan lapangan usaha bagi peternak, sehingga akan diperoleh peningkatan pendapatan dari usaha tersebut (Taslim, 2011).

Tenaga kerja dalam bidang peternakan dibedakan atas tenaga kerja keluarga dan luar keluarga. Tenaga kerja luar keluarga umumnya merupakan tenaga kerja bayaran. Jumlah keluarga juga mencerminkan tersedianya tenaga kerja untuk usaha ternaknya dimana suami, istri dan anak-anaknya semuanya terlibat dalam kegiatan usaha peternakan. Penyediaan tenaga kerja keluarga yang lebih banyak akan mengakibatkan usaha akan lebih maju (Winarno, 1985).

Tenaga kerja yang berasal dari keluarga petani merupakan sumbangan keluarga terhadap produksi pertanian atau peternakan yang secara keseluruhan tidak pernah dibayar dengan uang (Mubyarto, 1989). Tingkat curahan tenaga kerja bervariasi sesuai dengan kondisi usaha yang dijalankan (Taslim, 2011). Curahan waktu kerja dapat dipengaruhi oleh berbagai faktor baik internal maupun eksternal (Fauziyah, dkk., 2014).

Dalam analisis ketenagakerjaan di bidang peternakan, penggunaan tenaga kerja dinyatakan oleh besarnya curahan tenaga kerja. Curahan tenaga kerja adalah besarnya tenaga kerja efektif yang dipakai (Soetriono, 2003).

Menurut Mangkuprawira (1984), setiap anggota rumah tangga dalam mengalokasikan waktu untuk berbagai kegiatan dipengaruhi oleh faktor-faktor di dalam dan di luar rumah tangganya. Faktor-faktor di dalam rumah tangga, misalnya usia, pengalaman, dan jumlah tanggungan rumah tangga. Sedangkan faktor luar rumah tangga, misalnya struktur sosial.

Teori alokasi waktu kerja didasarkan pada teori utilitas. Alokasi waktu individu dihadapkan pada dua pilihan yaitu bekerja atau tidak bekerja untuk menikmati waktu luangnya. Bekerja berarti menghasilkan upah yang selanjutnya akan meningkatkan pendapatan. Meningkatnya pendapatan dapat digunakan untuk membeli barang-barang konsumsi yang dapat memberikan kepuasaan (Nalinda, 2006).
Analisis mengenai curahan tenaga kerja merupakan analisis tentang penawaran tenaga kerja yang pada prinsipnya membahas keputusan anggota rumah tangga dalam pilihan jam kerjanya. Individu anggota rumah tangga dalam mengalokasikan jam kerjanya akan bertindak rasional, yaitu memaksimalkan utilitas. (Rochaeni dan Lokollo, 2005).

Menurut Handayani dan Artini (2009), ada jenis-jenis kegiatan yang memerlukan curahan waktu yang banyak dan kontinu, tapi sebaliknya ada pula jenis-jenis kegiatan yang memerlukan curahan waktu kerja yang terbatas.

Beberapa hasil penelitian menunjukkan bahwa curahan waktu kerja dipengaruhi oleh: umur, pendidikan, jumlah anggota keluarga dan jumlah ternak yang dipelihara (Yunitas, 2005), umur, pendapatan di luar usahatani, luas lahan garapan, jumlah anggota keluarga dan jumlah ternak yang dipelihara (Hartono, 2005), jumlah ternak yang dipelihara (Alam, 2013), pendidikan dan jumlah ternak yang dipelihara (Rosmawati, 2014), umur, pengalaman, pendidikan dan luas lahan (Fauziyah, dkk., 2014).

Berdasarkan uraian di atas, maka diajukan hipotesis penelitian sebagai berikut: variabel jumlah kepemilikan ternak, jumlah anggota keluarga, pekerjaan utama dan penyuluhan berpengaruh terhadap curahan waktu kerja pada usaha penggemukan sapi potong, baik secara simultan maupun parsial.

\section{METODE PENELITIAN}

Kabupaten Ciamis diambil secara purposif sebagai lokasi penelitian dengan pertimbangan merupakan salah satu sentra produksi sapi potong di Provinsi Jawa Barat. Penelitian dilaksanakan dengan menggunakan metode survai. Menurut Singarimbun (1989), penelitian survai adalah penelitian yang mengambil sampel dari satu populasi dan menggunakan kuesioner sebagai alat pengumpulan data yang pokok.

Kecamatan Panjalu dan Cihaurbeuti dipilih secara purposif sebagai lokasi penelitian dengan pertimbangan merupakan sentra produksi usaha penggemukan sapi potong di Kabupaten Ciamis.

Peternak di Kecamatan Panjalu yang melaksanakan usaha penggemukan sapi potong sebanyak 102 orang, sedangkan di Kecamatan 


\section{Faktor-Faktor Yang Berpengaruh Terhadap Curahan Waktu Kerja \\ Pada Usaha Penggemukan Sapi Potong di Kabupaten Ciamis}

AGUS YUNIAWAN ISYANTO

Cihaurbeuti sebanyak 47 orang; sehingga ukuran populasi dari kedua kecamatan tersebut sebanyak 149 orang. Penentuan ukuran sampel dilakukan dengan menggunakan rumus Slovin (Unam, 2012) dengan marjin kesalahan 5\%. Ukuran sampel penelitian yang diperoleh sebanyak 100 peternak.

Data yang digunakan dalam penelitian ini berupa data primer yang diperoleh melalui wawancara dengan menggunakan kuesioner yang telah dipersiapkan sebelumnya. Data primer yang dikumpulkan terdiri atas karakteristik individu peternak dan data pemeliharaan sapi potong selama kurun waktu tahun 2012.

Variabel-variabel yang digunakan dalam penelitian ini adalah:

- Curahan waktu kerja (Y) adalah banyaknya waktu dari peternak yang digunakan dalam usaha penggemukan sapi potong, dan diukur dalam satuan jam per hari (jam/hari).

- Jumlah kepemilikan ternak $\left(\mathrm{X}_{1}\right)$ adalah banyaknya ternak sapi potong yang dimiliki oleh peternak, dan diukur dalam satuan ternak (ST).

- Jumlah anggota keluarga $\left(\mathrm{X}_{2}\right)$ adalah banyaknya anggota keluarga peternak, dan diukur dalam satuan orang (orang).

- Pekerjaan utama $\left(\mathrm{X}_{3}\right)$ adalah variabel dummy dari pekerjaan utama peternak, yang bernilai 2 jika pekerjaan utama adalah petani, bernilai 1 jika butuh tani, dan bernilai 0 untuk lainnya.

- Penyuluhan $\left(\mathrm{X}_{4}\right)$ merupakan variabel dummy yang bernilai 1 jika peternak mengikuti penyuluhan, dan bernilai 0 untuk lainnya.

Faktor-faktor yang berpengaruh terhadap curahan waktu kerja dianalisis dengan menggunakan persamaan regresi linier berganda sebagai berikut:

$$
\begin{aligned}
\mathbf{Y}=\mathbf{b}_{\mathbf{0}}+ & \mathbf{b}_{\mathbf{1}} \mathbf{X}_{\mathbf{1}}+\mathbf{b}_{\mathbf{2}} \mathbf{X}_{\mathbf{2}}+\mathbf{b}_{\mathbf{3}} \mathbf{X}_{\mathbf{3}}+\mathbf{b}_{\mathbf{4}} \mathbf{X}_{\mathbf{4}} \\
\text { Dimana: } & \\
\mathrm{Y}= & \text { Curahan waktu kerja (jam/hari) } \\
\mathrm{X}_{1}= & \text { Jumlah kepemilikan ternak }(\mathrm{ST}) \\
\mathrm{X}_{2}= & \text { Jumlah anggota keluarga (orang) } \\
\mathrm{X}_{3}= & \text { Pekerjaan utama, merupakan variabel } \\
& \text { dummy yang bernilai } 2 \text { jika petani, } \\
& \text { bernilai 1 jika buruh tani, dan bernilai 0 } \\
& \text { untuk lainnya. } \\
\mathrm{X}_{4}= & \text { Penyuluhan, merupakan variabel dummy } \\
& \text { yang bernilai 1 jika ikut penyuluhan, dan } \\
& \text { bernilai 0 untuk lainnya. } \\
\mathrm{b}= & \text { Koefisien regresi }
\end{aligned}
$$

Pendugaan parameter regresi linier berganda tersebut dilakukan dengan menggunakan program SPSS versi 16.

Pengujian hipotesis faktor-faktor yang berpengaruh terhadap produktivitas dilakukan dengan cara sebagai berikut:

- Pengujian secara simultan dengan uji-F. Pengujian dilakukan terhadap hipotesis: $\mathrm{H}_{0}$ : $\mathrm{b}_{1}=\mathrm{b}_{2}=\ldots=\mathrm{b}_{\mathrm{i}}=0$. Hipotesis diterima jika nilai statistik F-hitung lebih kecil atau sama dengan F-tabel, berarti variabel bebas secara simultan tidak berpengaruh signifikan terhadap variabel terikat. Jika nilai statistik F-hitung lebih besar dari F-tabel, maka hipotesis ditolak yang menunjukkan bahwa variabel bebas secara simultan berpengaruh signifikan terhadap variabel terikat.

- Pengujian secara parsial dengan uji-t. Pengujian dilakukan terhadap hipotesis: $\mathrm{H}_{0}$ : $b_{i}=0$. Hipotesis diterima jika nilai statistik t-hitung lebih kecil atau sama dengan t-tabel, berarti variabel bebas secara parsial tidak berpengaruh signifikan terhadap variabel terikat. Jika nilai statistik t-hitung lebih besar dari t-tabel, maka hipotesis ditolak yang menunjukkan bahwa variabel bebas secara parsial berpengaruh signifikan terhadap variabel terikat.

\section{HASIL DAN PEMBAHASAN Curahan Waktu Kerja}

Curahan waktu kerja pada usaha penggemukan sapi potong berkisar antara 2,14$5,10 \mathrm{jam} / \mathrm{hari}$, dengan rata-rata $3,65 \mathrm{jam} / \mathrm{hari}$.

Usaha penggemukan sapi potong merupakan pekerjaan sampingan bagi seluruh responden penelitian. Sedangkan pekerjaan utama peternak bervariasi, baik sebagai petani, buruh tani, guru, TNI, dan pekerjaan lain non usahatani.

Jumlah ternak sapi potong yang dimiliki oleh peternak berkisar antara 0,50-3,00 ST, dengan rata-rata 1,16 ST. Hubungan antara pekerjaan utama, jumlah kepemilikan ternak sapi potong dan curahan waktu kerja disajikan pada Tabel 1. 


\section{MIMBAR \\ A GRIBISNIS \\ ISSN 2460-4321}

Volume 1・Nomor 1・Juli 2015

Tabel 1. Hubungan Pekerjaan Utama, Jumlah Kepemilikan Ternak dan Curahan Waktu Kerja

\begin{tabular}{|c|c|c|}
\hline $\begin{array}{c}\text { Pekerjaan } \\
\text { Utama }\end{array}$ & $\begin{array}{c}\text { Rata-rata } \\
\text { Jumlah } \\
\text { Kepemilikan } \\
\text { Ternak (ST) }\end{array}$ & $\begin{array}{c}\text { Rata-rata } \\
\text { Curahan } \\
\text { Waktu Kerja } \\
\text { (jam/hari) }\end{array}$ \\
\hline Petani & 1,19 & 3,745 \\
\hline Buruh tani & 0,94 & 3,587 \\
\hline Lainnya & 1,18 & 3,149 \\
\hline
\end{tabular}

Sumber: Analisis Data Primer, 2015

Tabel 1 menunjukkan bahwa rata-rata curahan waktu kerja pada usaha penggemukan sapi potong akan meningkat jika pekerjaan utama responden di bidang usahatani, baik sebagai petani maupun buruh tani. Terlihat bahwa rata-rata curahan waktu kerja petani lebih tinggi jika dibandingkan dengan buruh tani. Hal ini disebabkan karena buruh tani harus mencurahkan waktunya lebih banyak pada pekerjaan utamanya sebagai buruh tani dalam upaya memenuhi kebutuhan hidup keluarganya,

Tabel 1 juga menunjukkan bahwa rata-rata kepemilikan ternak sapi potong pada petani (1,19 ST) lebih tinggi jika dibandingkan dengan pekerjaan utama lainnya $(1,18 \mathrm{ST})$ dan buruh tani (0,94 ST).

Rata-rata kepemilikan ternak sapi potong pada pekerjaan utama responden sebagai buruh tani lebih rendah jika dibandingkan dengan pekerjaan utama lainnya, namun rata-rata waktu kerja yang dicurahkan pada buru tani $(3,587$ jam/hari) jika dibandingkan dengan pekerjaan utama lainnya $(3,149$ jam/hari). Hal ini menunjukkan bahwa meskipun usaha penggemukan ternak sapi potong merupakan usaha sampingan bagi buruh tani, namun usaha tersebut penting baginya sehingga banyak waktu kerja yang dicurahkannya.

Menurut Budiraharjo, dkk. (2011) dan Mulyo, dkk. (2012), tujuan beternak sapi potong selain untuk mendapatkan keuntungan, juga sebagai tabungan apabila membutuhkan uang dan memanfaatkan kotoran ternak untuk usahataninya.

\section{Faktor-faktor yang Berpengaruh Terhadap Curahan Waktu Kerja}

Analisis faktor-faktor yang berpengaruh terhadap curahan waktu kerja pada usaha penggemukan sapi potong disajikan pada tabel 2.
Tabel 2. Faktor-faktor yang Berpengaruh Terhadap Curahan Waktu Kerja

\begin{tabular}{|l|r|r|r|}
\hline Variabel & $\begin{array}{c}\text { Nilai } \\
\text { Parameter }\end{array}$ & t-hit & Sig. \\
\hline Intersep & 1,139 & 0,074 & $15,314^{* *}$ \\
$\mathrm{X}_{1}$ & 0,469 & 0,054 & $8,660^{* *}$ \\
$\mathrm{X}_{2}$ & $-0,018$ & 0,048 & $-0,379^{\mathrm{ns}}$ \\
$\mathrm{X}_{3}$ & 0,068 & 0,027 & $2,554^{*}$ \\
$\mathrm{X}_{4}$ & 0,009 & 0,042 & $0,224^{\mathrm{ns}}$ \\
\hline $\mathrm{R}^{2}=0,493$ \\
F-hit = 23,110** \\
\hline
\end{tabular}

Sumber: Analisis Data Primer, 2015

Keterangan:

$* *, *=$ signifikan pada $1 \%$ dan $5 \%$

Nilai koefisien determinasi $\left(\mathrm{R}^{2}\right)$ sebesar 0,493 menunjukkan bahwa curahan waktu kerja pada usaha penggemukan sapi potong di Kabupaten Ciamis dapat dijelaskan sebesar $49,30 \%$ oleh variabel-variabel yang ada di dalam model, sedangkan sisanya sebesar $50,70 \%$ dijelaskan oleh variabel-variabel lain yang tidak dimasukkan ke dalam model.

Nilai F-hit sebesar 23,110 pada taraf nyata $1 \%$ menunjukkan bahwa seluruh variabel yang ada di dalam model secara simultan berpengaruh sangat signifikan terhadap curahan waktu kerja pada usaha penggemukan sapi potong.

Jumlah kepemilikan ternak $\left(\mathrm{X}_{1}\right)$ berpengaruh signifikan terhadap curahan waktu kerja pada usaha penggemukan sapi potong. Koefisien regresi bertanda positif menunjukkan bahwa semakin banyak ternak sapi potong yang dimiliki oleh peternak, maka akan semakin meningkat curahan waktu kerjanya. Hasil penelitian ini sejalan dengan hasil penelitian Hartono (2005), Yunilas (2005), Amalo, dkk. (2012), Alam (2013) dan Rosmawati (2014).

Hernanto (1996) menyatakan bahwa pemeliharaan ternak di Indonesia hampir seluruhnya dilakukan dalam skala kecil dan merupakan kerja sampingan. Jumlah ternak pengaruhnya sangat nyata dan berperan positif terhadap curahan waktu kerja. Semakin tinggi skala usaha maka curahan waktu kerja, maka akan semakin bertambah, begitupun sebaliknya.

Jumlah anggota keluarga $\left(\mathrm{X}_{2}\right)$ tidak berpengaruh signifikan terhadap curahan waktu kerja pada usaha penggemukan sapi potong. Koefisien regresi bertanda negatif menunjukkan bahwa semakin banyak jumlah anggota keluarga, maka semakin menurun curahan 


\section{Faktor-Faktor Yang Berpengaruh Terhadap Curahan Waktu Kerja \\ Pada Usaha Penggemukan Sapi Potong di Kabupaten Ciamis}

AGUS YUNIAWAN ISYANTO

waktu kerjanya. Hal ini disebabkan karena semakin banyak jumlah anggota keluarga, maka peternak akan lebih banyak mencurahkan waktunya untuk bekerja pada bidang lain yang dapat memberikan pendapatan dengan segera untuk memenuhi kebutuhan hidup keluarganya.

Pekerjaan utama $\left(\mathrm{X}_{3}\right)$ berpengaruh signifikan terhadap curahan waktu kerja pada usaha penggemukan sapi potong. Koefisien regresi bertanda positif menunjukkan bahwa jika pekerjaan utama peternak berkaitan dengan usahatani, baik sebagai petani maupun buruh tani; maka akan semakin meningkat curahan waktu kerjanya.

Peternak yang mempunyai pekerjaan utama non pertanian tentunya akan lebih mencurahkan waktu kerjanya pada pekerjaan utamanya tersebut, apalagi jika kontribusi pendapatan dari usaha penggemukan sapi potong lebih kecil dibandingkan dengan kontribusi pendapatan dari pekerjaan utamanya.

Penelitian Ginting (2013) menunjukkan bahwa pendapatan yang diperoleh dari usaha penggemukan sapi potong memberikan kontribusi sebesar $22,07 \%$ terhadap pendapatan total keluarga petani.

Penyuluhan $\left(\mathrm{X}_{4}\right)$ tidak berpengaruh signifikan terhadap curahan waktu kerja pada usaha penggemukan sapi potong. Koefisien regresi bertanda positif menunjukkan bahwa semakin banyak peternak mengikuti kegiatan penyuluhan, maka akan semakin meningkat curahan waktu kerjanya.

Penyuluhan dapat memotivasi peternak untuk meningkatkan produktivitas ternaknya, sehingga curahan waktu kerjanya akan meningkat. Penelitian Widodo dan Sunarso (2009), Akudugu, et al (2012) dan Assis, et al (2014) menunjukkan bahwa penyuluhan dapat meningkatkan produktivitas melalui keputusan petani dalam mengadopsi teknologi baru yang diperoleh melalui kegiatan penyuluhan.

\section{PENUTUP}

Berdasarkan hasil dan pembahasan dapt disimpulkan hal-hal sebagai berikut.

1. Curahan waktu kerja pada usaha penggemukan sapi potong berkisar antara 2,14-5,10 jam/hari, dengan rata-rata 3,65 jam/hari.

2. Jumlah kepemilikan ternak dan pekerjaan utama berpengaruh positif dan signifikan terhadap curahan waktu kerja pada usaha penggemukan sapi potong.

\section{DAFTAR PUSTAKA}

Akudugu, M.A., Guo, E., dan Kwesi Dadzie, S.K. 2012. Adoption of Modern Agricultural Production Technologies by Farm Households in Ghana: What Factors Influence their Decisions? Journal of Biology, Agriculture and Healthcare, 2(3): 1-13.

Alam, A. 2013. Curahan Waktu Kerja Keluarga pada Usaha Peternakan Kambing di Kecamatan Leihitu Kabupaten Maluku Tengah. Agrinimal, 3(2): 51-55.

Amalo, S., Hartono, B., dan Utami, H.D. 2012. Model Simulasi Peningkatan Ternak Sapi Induk Pola Gaduhan terhadap Curahan Tenaga Kerja: Studi Kasus di Kecamatan Amanuban Selatan, Propinsi Nusa Tenggara Timur. Sains Peternakan Vol. 10 (1), Maret 2012: 30-38.

Assis, K., Nurul Azzah, Z., dan Mohammad Amizi, A. 2014. Relationship Between Socioeconomic Factors, Income and Productivity of Farmers: A Case Study on Pineapple Farmers. IJRHAL, 2(12): 67-78.

Budiraharjo, K., Handayani, M. dan Sanyoto, G. 2011. Analisis Profitabilitas Usaha Penggemukan Sapi Potong di Kecamatan Gunungpati Kota Semarang. Mediagro, 7(1): 1-9.

Fauziyah, E., Diniyati, D., dan Widyaningsih, T.S. 2014. Curahan Waktu Kerja Sebagai Indikator Keberhasilan Pengelolaan Hutan Rakyat "Wanafarma " di Kecamatan Majenang Kabupaten Cilacap. Jurnal Penelitian Hutan Tanaman, 11(1): 53-63.

Ginting, A.B. 2013. Kontribusi Usahatani Padi dan Usaha Sapi Potong Terhadap Pendapatan Keluarga Petani di Kecamatan Purwodadi Kabupaten Grobogan Provinsi Jawa Tengah. VISI, 21(2): 1306-1314.

Hadi, P.U., A. Thahar, N. Ilham, and B. Winarso. 2002. A Progress report summary: analytic framework to facilitate development of Indonesia's beef industry. Paper Presented at the "Routine Seminar". Center for Agro Socio Economic Research and Development. Bogor, 8 Maret 2002. $24 \mathrm{p}$.

Hadi, P.U. dan T.B. Purwantini. 1991a. Kajian Pola Produksi Pertanian Lahan Kering di 


\section{MIMBAR \\ A GRIBISNIS \\ ISSN 2460-4321}

Volume 1・ Nomor 1・Juli 2015

Kabupaten Bima - Nusa Tenggara Barat. Laporan Hasil Penelitian. Pusat Penelitian Sosial Ekonomi Pertanian, Bogor. 121 hlm.

Hadi, P.U. dan T.B. Purwantini. 1991b. Kajian Pola Produksi Pertanian Lahan Kering di Kabupaten Sumba Timur - Nusa Tenggara Timur. Laporan Hasil Penelitian. Pusat Penelitian Sosial Ekonomi Pertanian, Bogor. $239 \mathrm{hlm}$.

Handayani, M.Th., dan Artini, N.W.P. 2009. Kontribusi Pendapatan Ibu Rumah Tangga Pembuat Makanan Olahan Terhadap Pendapatan Keluarga. Piramida, V(1): 9 hal.

Hartono, B. 2005. Curahan Tenaga Kerja Keluarga di Usaha Ternak Sapi Perah: Kasus di Desa Pandesari, Kecamatan Pujon, Kabupaten Malang, Jawa Timur. Buletin Peternakan, 1(29): 131-138.

Hernanto, F. 1996. Ilmu Usaha Tani. Jakarta: Penebar Swadaya.

Mangkuprawira, S. 1984. Alokasi Waktu dan Kontribusi Kerja Anggota Keluarga dalam Kegiatan Ekonomi Rumah tangga : Studi Kasus di Dua Tipe Desa di Kabupaten Sukabumi Jawa Barat. Disertasi Doktor. Program Pascasarjana IPB. Bogor

Mubyarto. 1989. Pengantar Ekonomi Pertanian. Edisi Ketiga. Jakarta: LP3ES.

Mulyo, I.T., Marzuki, S., dan Santoso, S.I. 2012. Analisis Kebijakan Pemerintah Mengenai Budidaya Sapi Potong di Kabupaten Semarang. Animal Agriculture Journal, 1(2): 266-277.

Nalinda, R. 2006. Alokasi Waktu Kerja Keluarga Pengrajin Emping Melinjo di Kecamatan Mlati Kabupaten Sleman. Jurnal Ilmu-Ilmu Pertanian, 2(1): 73-86.

Priyanto, D. 2011. Strategi Pengembangan Usaha Ternak Sapi Potong dalam Mendukung Program Swasembada Daging Sapi dan Kerbau Tahun 2014. Jurnal Litbang Pertanian, 30(3): 104-116.

Rahmanto, B. 2004. Analisis Usaha Peternakan Sapi Potong Rakyat. ICASERD Working Paper No. 59. Pusat Penelitian dan Pengembangan Sosial Ekonomi Pertanian. Badan Penelitian dan Pengembangan Pertanian. Departemen Pertanian.

Rochaeni, S., dan Lokollo, E.M. 2005. FaktorFaktor yang Mempengaruhi Keputusan
Ekonomi Rumah Tangga Petani di Kelurahan Setugede Kota Bogor. Jurnal Agro Ekonomi, 23(2): 133-158.

Rosmawati, H. 2014. Analisis Curahan Waktu Tenaga Kerja Wanita pada Usaha Ternak Sapi Potong di Desa Mendayun Kecamatan Madang Suku I Kabupaten OKU Timur. Jurnal Ilmiah AgrIBA, No. 2, Edisi Maret Tahun 2014: 17-26.

Singarimbun, M. 1989. Metode Penelitian Survai. Jakarta: LP3S .

Soetriono. 2003. Pengantar Ilmu Pertanian. Jember: Bayumedia.

Taslim. 2011. Pengaruh Faktor Produksi Susu Usahaternak Sapi Perah Melalui Pendekatan Analisis Jalur di Jawa Barat. Jurnal Ilmu Ternak, 10(1): 52-56.

Unam, J.M. 2012. Materials Management for Business Success: The Case of the Nigerian Bottling Company Plc. International Journal of Economics and Management Sciences, 1(7): 50-56.

Widodo dan Sunarso. 2009. Pengaruh Penyuluhan, Motivasi dan Disiplin Kerja Terhadap Produktivitas Kerja Kelompok Tani. Jurnal Manajemen Sumberdaya Manusia 3(1): 47-56.

Winarno. 1985. Analisis Manajemen dan Pemasaran Susu Usaha Peternakan Sapi Perah Rakyat dan Perusahaan Sapi Perah di Kotamadya Yogyakarta. Tesis S2. UGM. Yogyakarta.

Winarso, B., Sajuti, R., dan Muslim, C. 2005. Tinjauan Ekonomi Ternak Sapi Potong di Jawa Timur. Forum Penelitian Agro Ekonomi, 23(1): 61-71.

Yunilas. 2005. Faktor-Faktor yang Mempengaruhi Curahan Waktu Tenaga Kerja Wanita dalam Pemeliharaan Ternak Sapi di Kecamatan Hamparan Perak. Jurnal Agribisnis Peternakan, 1(3): 117122.

Yusdja, Y., dan Ilham, N. 2004. Tinjauan Kebijakan Pengembangan Agribisnis Sapi Potong. AKP, 2(2): 183-203.

2007. Suatu Gagasan Tentang Peternakan Masa Depan dan Strategi Mewujudkannya. Forum Penelitian Agro Ekonomi, 25(1): 19-28. 